\title{
Etnografia dissonante dos tribunais do júri
}

\author{
Ana Lúcia Pastore Schritzmeyer
}

Como quase todas as outras instituições permanentesa religião, a arte, a ciência, o estado, a família -, 0 direito está envolvido em um processo de aprender a sobreviver sem as certezas que 0 geraram.

GeerTZ, 1998, p. 328

\section{Fio condutor}

N ão se passam muitos meses sem que um caso de homicídio doloso, já al ardeado pela mídia à época de sua ocorrência, volte a ensejar debates em jornais, revistas, emissoras de rádio eTV, pois o réu ou ré finalmente che gou a julgamento pelo júri popular. N essas ocasiões, reeditam-se e alargamse discussões recorrentes entre magistrados, promotores, advogados, dele gados de polícia, professores e estudantes de direito. Elas se referem, grosso modo, à pertinência, em um regime democrático, de jurados leigos julgarem os crimes mais duramente apenados no Brasil: os dolosos contra a vida homicídio, aborto, infanticídio e indução ao suicídio. A queles que se envolvem nesses debates geralmente estão polarizados entre favoráveis e contrários à permanência do júri no sistema de justiça criminal brasileiro, levantando argumentos variados, resumidos no quadro a seguir

1. Apesar de os quatro tipos penais serem da competência do Tribunal do Júri, raramente chegam a julgamento casos distintos dos de homicídios dolosos tentados ou consumados. Ver Código Penal Brasileiro, arts. 121 a 124, e Código de Processo Penal Brasileiro, arts. 439 a 497. 
FAVORÁVEIS

a) É um tribunal de conotação democrática.
CONTRÁRIOS

a) Em muitos países democráticos não há mais júri (França, Alemanha, Bégica, Itália, Grécia etc.) e, mesmo nos Estados U nidos, em várias situações, cabe ao réu decidir se vai ou não a júri.

b) Jurados estão mais em contato com b) Juízes togados também são cidadãos e os contextos em julgamento do que juíparticipam da sociedade, além de terem estudado para melhor compreendêla; jurados são suscetíveis a injunções.

c) Se o jurado pode ser suscetível a influências externas, o juiz togado pode seguir ideologias e convicções próprias.

c) Juízes togados passam por longo período de preparo profissional parajulgar com imparcialidade.

d) Considerações não técnicas, mas morais, éticas, psicológicas e econômicas orientam os jurados em suas decisões, dosando eventuais injustiças da aplicação "pura e fria" da lei.

d) N os debates do júri preval ecem argumentos emocionais e fal sos que iludem os jurados e os fazem perder de vista a imparcialidade necessária a um bom julgamento.

e) Legisladores, assim como jurados, podem ser leigos, pois o que importa é o "bom senso".

e) Jurados geral mentenão têm "bom senso jurídico", podendo desprezar provas importantes por motivos emocionais.

f) 0 júri contribui para a administração da justiça e garante o princípio da publicidade dos atos ao exigir dos profissionais um linguajar acessível a leigos.

g) 0 júri tem um caráter educacional sobre a população, pois as sessões são como “[...] laboratórios onde se experimenta 0 direito concreto e o próprio sentimento f) A complexidade dos crimes que vão a júri exige rigor técnico na exposição e apreciação de provas.

g) O s julgamentos pelo júri, por serem mais morosos que os demais, aumentam a sensação social de impunidade e a de que o Poder Judiciário não funciona.

2. Extraído de Almei- dajustiça [...]"2. da (1977, p. 19).

\begin{tabular}{|c|c|}
\hline $\begin{array}{l}\text { Pesquisas apontam que o júri não } \\
\text { mete mais erros do que tribunais não } \\
\text { opulares. }\end{array}$ & $\begin{array}{l}\text { h) Pesquisas apontam que o júri comete } \\
\text { mais erros do que tribunais não popula- } \\
\text { res. }\end{array}$ \\
\hline $\begin{array}{l}\text { i) } 0 \text { júri atende, de modo eficaz, a vários } \\
\text { princípios processuais, como acusação, } \\
\text { audiência, contraditório, oralidade etc. }\end{array}$ & $\begin{array}{l}\text { i) Soluções "extralegais" de muitos vere- } \\
\text { dictos desprestigiam a Justiça. }\end{array}$ \\
\hline $\begin{array}{l}\text { Presume-se que as decisões do júri } \\
\text { incidam com a opinião popular e por } \\
\text { a possam ser melhor assimiladas. }\end{array}$ & $\begin{array}{l}\text { j) A maioria dos jurados não expressa } \\
\text { a opinião popular, mas interesses da clas- } \\
\text { se média da qual provêm. }\end{array}$ \\
\hline
\end{tabular}


Retomo este quadro, elaborado à época de meu doutorado (cf. Schritzmeyer, 2002, p. 61), para precisar que o recorte deste artigo não aprofundará tais questões técnico-político-jurídicas, nem abordará aquelas mais recentemente veiculadas pela mídia. Tampouco pretendo sugerir alguma resolução para a celeuma de se 0 júri deve ou não permanecer no ordenamento jurídico brasileiro, pois, por meio dessas frentes, o material social em análise consistiria em discursos produzidos sobreo júri, eo queme interessa é analisar discursos produzidos no júri.

A partir da etnografia que realizei, entre 1997 e 2001, nos cinco Tribunais do Júri da cidade de São Paulo, e de reflexões que desenvolvo desde então, pretendo questionar se tribunais, em geral, e os do júri, em particular, se esgotam como arenas de luta nas quais o binômio dominação-sujeição se realiza de forma privilegiada. Intento sustentar que, embora nesses espaços observemos rituais de caráter lúdico e agonístico que reiteram certas hierarquias tradicionalmente estabelecidas, eles também permitem, em alguma medida, a construção de novas subjetividades e a redefinição de experiências sociais.

Trata-se de assumir a tese de que é possível perceber as sessões de julgamento pelo júri como mais do que uma manipulação de imagens que representantes de camadas médias e elites - jurados, operadores do direito, juízes - fazem de assassinatos envolvendo indivíduos pobres. C onsidero que, conforme as mortes são relatadas durante as sessões de julgamento, todos os partici pantes, ainda que de diferentes modos e com intensidades diversas, expõem-se a uma experiência coletiva que, como tal, guarda certo potencial transformador.

Para desenvolver esse argumento, parto da metodologia, proposta por G eertz, segundo a qual uma antropologia jurídica ou do direito não deve caracterizar-se pelo esforço de "[...] corrigir raciocínios jurídicos através de descobertas antropológicas, e sim [por] um ir e vir hermenêutico entre os dois campos, [...] a fim de formular as questões morais, políticas e intelectuais que são importantes para ambos" (G eertz, 1998, p. 253).

N essa chave, sessões de júri serão tomadas como "[...] obras imaginativas construídas a partir de materiais sociais" (Geertz, 1978, pp. 316-317) ou "estruturas simbólicas coletivamenteorganizadas que dizem al guma coisa sobre algo" (Idem, pp. 316-321). 
Obras imaginativas

Pensar os julgamentos como textos literários que utilizam emoções para fins cognitivos implica uma "análise semântica" baseada no pressuposto de que se pode ler uma sessão de júri, " [... ] um ritual ou uma cidade, da mesma maneira como se pode ler um conto popular ou um texto filosófico. 0 método de exegese pode variar, mas, em cada caso, a leitura éfeita em busca do significado" (D arnton, 1986, p. XVI).

Um aspecto a aprofundar nesse tipo de análise é o caráter pedagógico dos julgamentos, pois assisti-los ou deles participar ativamente é expor-se a uma "espécie de educação sentimental" (G eertz, 1978, p. 317), uma vez que, nos plenários do júri, o ethos que se apresenta como dominante é "soletrado em um texto coletivo" (I dem), permitindo aos presentes tomar alguma consciência de si e dos outros nesse conjunto.

N as sessões de júri, os princi pais "soletradores" são os advogados dos réus e representantes do M inistério Público (promotores de justiça), pois conduzem assustentaçõesorais como sefossem um tipo de "aula expositiva". Q uando essas se encerram, jurados são chamad os a aplicar o que "apre(e)nderam", tendo de, necessariamente, optar por uma das versões narradase, assim, produzir uma decisão a respeito decomo acusadosevítimasagiram e, principalmente, deveriam agir em dado contexto emocional. Isso implica dizer que o principal desafio apresentado aosjuradoséo deavaliar o quanto certas emoções, em certas circunstâncias, legitimam ou não o desfecho morte. Esse éo material social que constitui o cernedo discurso produzido no júri.

Em muitas sessões, cada um dos espectadores, especialmente osjurados, à medida que ouvem e observam o desenrolar do julgamento, reconhecem ou não seus próprios valores articulados no discurso de um ou vários "atores" - juiz, promotor, defensor, réu, testemunhas - , de modo que o resultado do julgamento, nesse sentido, é o desfecho de um processo especular, geralmente sinuoso e indireto. Como em uma sala de espelhos, na qual quem se coloca diante deles se vê multiplicado ou mesmo transfigurado, estranhando-se ou reconhecendo-se, em sessões de júri as argüições absorvem, multiplicam, desfiguram e reconfiguram valores dos participantes.

Além disso, o que mais me parece digno de nota é que, quanto mais os casos em julgamento envolviam "gente da periferia" ou de "camadas populares", mais alguns jurados de "classe média" declararam, em entrevistas, sentir-se seguros para julgar. Eles justificaram tal segurança com base em uma imparcialidade ou "distanciamento crítico", mas ocorreu-me pensar se 
justamente projeções e identificações profundas - proximidades afetivas não se dão de modo tanto mais eficaz quando mais o outro parece estranho, "exótico", um "avesso".

A própria história da antropologia, em certa medida, ensina-noso quanto resultou de complexas projeções o fato de os primeiros antropólogos identificarem nos "selvagens" o passado do homem europeu, branco e "civilizado". Julgar o aparentemente distante e até ficcional parece facilitar o que, em al guma medida, talvez se bloqueie diante do próximo e "real".

Perguntei, certa vez, a um jurado 3 :

Eu: Em algum momento, o senhor se identificou com a ré ou com seu marido, quer dizer, colocou-se no lugar deles?

JuRAdo: N ão, eles são muito diferentes de mim. Vivem noutra realidade, o que, aliás, me dá melhores condições de julgar. M as acho que consegui imaginar o que a vítima sentiu.

Eu: 0 senhor acha que a realidade da vítima é mais parecida com a sua do que a do réu?

JuRAd o: N ão! N ão. Eu não diria isso, quer dizer... 0 que eu acho éque, pelo visto, a vítima, como a maioria dos genros, tem sempre muitos defeitos aos olhos dos sogros, ainda mais das sogras. Afinal, não éà toa que falam tanto mal delas. U ma sogra, quando o casamento da filha vai mal, sempre acha que a culpa é do genro. Q ueeleéqueé um mau caráter. Essa hi stória não muda, sabe? Q uer dizer, não éque minha sogra queira me matar eque todas as sogras queiram matar seus genros, mas essa sogra que nós julgamos hoje representa muitas que andam por aí: ar humilde, inofensivo, mas, por baixo, são verdadeiras feras, capazes de mandar matar os genros pagando os assassinos com umaTV (grifos meus).

Julgar a sogra que mandou matar o genro, na distante periferia paulistana do Jardim Ó rion, e mesmo julgar "as sogras", em geral, talvez seja mais fácil do quejulgar a própria sogra, tanto queessejurado seexclui da regra de ter uma sogra que o persegue. M as é muito provável que ao julgar a "sograÓ rion", sem se dar conta, ele se identifique com o "genro-Ó rion".

As impressões de jurados a respeito da vida, assim como as de todos nós, são colhidas assistematicamente, a partir das mais diversas situações cotidianas, e a maior parte do tempo elas permanecem frouxas e desorganizadas. Situações como a de um julgamento pelo júri coordenam e permitem focalizar parte dessas impressões, revelando-as, a nós mesmos, por meio de sentimentos e reações despertados.
3. Entrevista concedida apóso julgamentoocorrido em 19/7/2001, no Plenário 8 do $1^{\stackrel{9}{\text { Tribu- }}}$ nal do úri daCidadede São Paulo. 
0 júri, portanto, põe em foco experiências da vida cotidiana, o que significa dizer que, ao mesmo tempo em queelas se destacam de espaços profanos, como ocorre em jogos ou rituais, religam-se a eles ao serem interpretadas como acontecimentos paradigmáticos. N os (des)compassos desse movimento entre profano esagrado, entre o queacontecee o quese gostaria que acontecesse, tais experiências, mais do que "reveladoras", criam, elaboram e constroem sensibilidades: " $Q$ uartetos, naturezas-mortas e brigas de galosnão são meros reflexos de uma sensibilidade preexistentee representadaanalogicamente: eles são agentes positivosna criação emanutenção detal sensibilidade" (G eertz, 1978, pp. 318-319).

Seguindo essa linha de raciocínio, parece correto afirmar que as sessões dejúri permitem a seus participantes ler e reler quanto equando élegítimo qualquer ser humano matar outro, enão apenas os casos em que seres humanos econômica, política e socialmente fragilizados se envolvem em homicídios. Embora esse seja o perfil majoritário de réus e vítimas, quem assiste a um julgamento normal mente se vê compelido a adequar a dimensão de sua própria subjetividade às mortes violentas narradas nos plenários, e tal ade quação sefaz ali, em ato, poiséna dinâmica das sessões quese opera um tipo específico e coletivo de criação eformatação de sensibilidades.

Cabe ainda registrar que nessas "aulas de educação sentimental", embora predomine, por parte dos "professores", o uso de uma linguagem aparentemente mais audiovisual que cinestésica, ou seja, de um sistema de signos que mais parece comunicar por meio do olhar e da audição do que de outras expressões corporais, os corpos "falam", o tempo todo, por meio de olhares que se procuram e se evitam, de sutis movimentos de lábios, sobrancel has que se arqueiam e se franzem, mãos que se esfregam, dedos que tamborilam, ombros que se curvam ese erguem, cabeças que balançam. Há mais sutilezas do que um observador, mesmo treinado, é capaz de registrar, pois "a força do poder do júri é audível, visível e palpável através de sua

4. No capítulo 4 deminhatesededoutorado "Júri-teatro" -, desenvolvo, especificamente, um debatesobreo cará ter teatral do júri. teatralidade" (Schritzmeyer, 2007, p. 18)4. Justamente por isso sua linguagem faz trânsitos importantes entre fatos e leis (cf. G eertz, 1998) ou entre ditos e feitos (cf. Peirano, 2002).

Linguagens poéticas

Segundo Steven Lubet, a linguagem poética éa mais adequada à construção de narrativas eficientes em tribunais, especial mente quando os acontecimentos aos quais se referem envolvem crimes (cf. Lubet, 2001). Partindo 
desse pressuposto, etnógrafos de sessões de júri não só observam linguagens poéticas, mas também, em al guma medida, fazem uso dela ao transcreverem observações para seus cadernos de campo e desses para relatórios de pesquisa. D eclarou Lubet, em entrevista tel efônica a um jornalista: “N ossa obrigação é recriar o passado por meio de palavras. M as o problema de nossa profissão é que o passado é algo irreproduzível. Como se recupera um crime que ocorreu há um ou doisanos? É impossível lembrar detodos os detalhes. Por isso, fazemos uma espécie de poesia" (apud Borges, 2001, p. 10).

Essa "recriação" do passado, do ausente, dos detalhes que escapam à lembrança ou do que a memória seleciona e o presente reconstrói é, em larga medida, o quetambém sefaz na sistematização de dados etnográficos. Certa vez, após um longo julgamento que durou aproximadamente dez horas, fiquei muito insatisfeita com meus registros, dada minha incapacidade de "anotar tudo" e, ao mesmo tempo, depois, de "recuperar tudo". Passadosalguns dias, reli "O inquisidor como antropólogo", deC arlo Ginzburg, e percebi que minhas tentativas de registrar as sessões de júri, com espantosa riqueza etnográfica, aproximavam-me dos escrivães de Friuli, na I tália dos séculosXVI-XVII: "As palavras, os gestos, o corar súbito do rosto, atéos silêncios- tudo era registrado com meticulosa precisão pelos escrivães do Santo O fício" (Ginzburg, 1989, p. 209).

Em que medida, assim como os inquisidores, não estava eu "extorquindo" das sessões os estereótipos que me interessavam? M as o próprio Ginzburg me acalmou: "A essência daquilo a que chamamos uma atitude antropológica [...] reside numa disposição dialógica" (Idem, p. 207), em criar e registrar situações em que vozes dissonantes e contraditórias não necessariamente se "encaixam" em modelos e teorias.

Assim, conclui que, enquanto advogados e promotores constroem narrativas nos tribunais a fim de transformar informações "desconexas" de testemunhas, réus, laudos etc. em uma "história bem contada", permitindo que jurados cheguem a um veredicto, antropólogos não precisam construir narrativas para necessariamente levar leitores a veredictos teóricos.

Afirma Lubet que um bom advogado, ao contar a história de seu cliente, devetomar o cuidado desó editar trechosquenão comprovem o crime (cf. Borges, 2001, p. 11). Penso que, embora a edição também seja inevitável em uma etnografia, justamenteseu fim deveser o denão omitir aquilo que questiona o próprio antropólogo eque, nessa medida, criatanto teses como antíteses.

Enquanto promotor e defensor, em plenário, normalmente arranjam a multiplicidadee a complexidadedossentidos relacionadosao acontecimen- 
5. $\mathrm{N}$ a tese de doutorado, analiso a dinâmica do júri à luz dosconceitos de jogo (cap. 1 e2), ritual (cap. 3) e drama (cap. 4), explorando suas potencialidades $\mathrm{e}$ limitaçõesparaessefim. to criminalizado demodo convenienteàs suasteses, antropólogosnão precisam reduzir a complexidade deseus objetos deanálisea modelos explicativos quecondigam com um único "formato antropológico" declassificar o mundo. É claro que, se etnografias, em alguma medida, não levarem em conta alguns "formatos" consensual menteadotadosna área, o trabal ho tal vez nem seja aceito como antropológico. 0 desafio é, diantedejulgamentosjudiciais quefornecem denso material analítico, não reduzir conflitoshumanosameras confirmações de conceitos, perdendo de vista idiossincrasias das múltiplasmotivações que, nem sempre, se "encaixam" bem em modelos.

Lubet, ainda tratando da produção de "verdades" nos tribunais, admite: "Toda observação é influenciada por aspectos psicológicos. D uas pessoas podem dizer a verdade, mas descrever situações diferentes. [...] há um espaço enorme para interpretações e reconstruções distintas dos fatos. É aí que está a habilidade do advogado" (I dem). Sua opinião é a de que tais "verdades", produzidas tanto por promotores como por advogados de defesa, quando "cinco passos de um rotei ro básico eideal" são seguidos à ris$\mathrm{ca}$, alcançam alto potencial de convencimento e produzem grandes julgamentos. Especialmente o último dos "cinco passos" - explicar as razões para os atos do crime; dissecar todos os fatos conhecidos; dispor de testemunhas com credibilidade; basear a história em detalhes precisos; tornar a narrativa plausível (cf. Lubet, 2001) - parece-me importante, pois a plausibilidade das narrativas, ou a verossimilhança do que é dito, é o que mais está em jogo no júri.

Enfim, talvez a principal diferença entre discursos elaborados tanto por antropólogoscomo por promotores eadvogados dejúri seja a de que, apesar de todos editarem informações, os primeiros podem produzir "boas argüições antropológicas", mesmo quando nelas apresentam ruídos e mais levantam dúvidas do que indicam veredictos.

Confirmando essa complexidade envolvida no ato de etnografar dissonâncias, destaco o fato de que, apesar de o júri exibir, enquanto forma dramática, uma estrutura atomística - cada julgamento équase um mundo em si mesmo -, o que, a princípio, facilitaria o acompanhamento de sua dinâmica, mal as sessões terminam seus participantes não as retêm com clareza objetiva, mas com lembranças difusas, pois, como qualquer forma expressiva, o júri só tem vida plena em seu próprio presente, aquele que ele mesmo cria (cf. G eertz, 1978, pp. 312-313).

0 modo, inclusive, como a noção de temporalidade é elaborada nas sessões de júri reproduz a compreensão de que o desenrolar da vida é um 
fluxo contínuo, um movimento unidirecional, com origem no passado e desenvolvimento inexorável do presente em direção ao futuro. 0 s acontecimentos narrados no júri parecem ganhar sentido ao serem organizados em horas, dias, cronologias, biografias, e a própria enumeração das peças processuais, nos autos, segue essa lógica que comprime multiplicidades em uma única seqüência cujo desfecho é uma sentença decisória. D esse ponto de vista, julgamentos pelo júri exemplificam uma percepção linear do passar do tempo e da vida. Apesar disso, há momentos das sessões em que afloram modos não dominantes de organizar o tempo, expondo as fissuras que qual quer sistema de pensamento carrega. I sso pode ser verificado espe cialmente quando o juiz interroga o réu e dele exige uma seqüência de respostas que normal mente não está elaborada em sua memória com aquela linearidade. $D$ ados exatos sobre dia, hora, local e pessoas presentes a um acontecimento ocorrido (ou não) há vários anos rearranjam-se ou mesmo se perdem na memória de quem, muitas vezes, passou a viver o tempo da vida prisional.

N os plenários também ocorrem requalificações de comportamentos. Alguns, socialmente censurados, ainda que apreciados e bastante praticados, como as "fofocas", ganham o rótulo judicial de provas (geralmente testemunhais), as quais, por meio de depoimentos, expõem a vida privada dos envolvidos, levantando, confirmando ou refutando suspeitas que sobre eles recaem. N esse sentido, os julgamentos expressam certo gosto, generalizado e velado, por julgar a vida al heia e, conseqüentemente, resolver nos outros - no réu absolvido ou condenado; na testemunha fidedigna ou desconfiável; na vítima sofredora ou "merecedora do que recebeu" - dilemas amorosos, familiares, de vizinhança, de trabalho, jamais resolvidos plenamente por ninguém (e em ninguém).

Como forma expressiva, portanto, o júri também arruma, desarruma e rearruma contextos semânticos, fornecendo um comentário metassocial de questões "vitais" envolvidas em mortes. Júri e antropologia talvez mostrem, de diferentes modos, a ordem poética que perpassa a vida social e o quanto é preciso interpretá-la para produzir um conhecimento dessas estórias sobre nós que contamos a nós mesmos (cf. Idem, pp. 315-316).

\section{Topografias}

Vale recordar, ainda explorando a idéia de prática etnográfica como leitura interpretativa de materiais sociais, que ao descreverem espaços urba- 
6. Especificamente sobreBraślia, ver $\mathrm{H}$ olston (1993).

7. São designadosanualmente mais de 11 mil jurados, inquiridas em torno de 8 mil testemunhas e realizados mais de mil julgamentos (cf. http://geocities.com/ tribjuri/SintH ist.htm).

8. Entrevista concedida em 2/8/2001. nos, como o palácio de Versalhes, o plano piloto de Braślia, recantos de Roma, a praça Zócalo na Cidade do M éxico ou a praça Vermelha, em M oscou, diferentes antropólogos os apontam como teatros em que o poder se mostra e se afirma: "A topografia simbólica de uma cidade é uma topografia social e política [...]. Certos lugares exprimem o poder eimpõem seu ar sagrado melhor do que qualquer explicação. [...] 0 espetáculo visual é suficiente, não sendo necessárias palavras" (Balandier, 1982, pp. 10-12)6.

Assim também, de certa forma, são os fóruns em que estão instalados os plenários do júri, como o novo Fórum Criminal M inistro M ário Guimarães, da cidade de São Paulo, inaugurado em 1999 e para o qual foi transferido o 1ำTribunal do Júri, ainda hoje o maior da América Latina.

D e inspiração nitidamente "N iemeyer", é um prédio de proporções gigantescas, de concreto e vidro, com linhas retas modelando seus limites e linhas curvas formando grandes arcadas através das quais há entradas, saídas e janelas. Circundado por uma grande área asfaltada, utilizada para estacionamento de veículos e que se reclina como uma praia ao redor de uma ilha, tem-se, de sua entrada principal, uma visão de praticamente 360 graus das cercanias. Ao longe, num dos horizontes, erguem-se prédios altos de vários bai rros e, do lado oposto, delineiam-se montanhas. 0 acesso ao local se dá por um conjunto de largas avenidas, próximas a uma das mais importantes vias de acesso à cidade: a M arginal do rio Tietê.

No interior do prédio, inicialmente planejado para ser um hospital, corredores largos também são denominados "avenidas", e outros mais estreitos recebem o nome de "ruas", todos identificados por números e letras. N um grande hall central, erguem-se rampas sobre um jardim em desnível, coberto por diferentes tipos de heras e plantas que recebem luz natural filtrada através de um grande teto envidraçado. Todo o conjunto é climatizado, pois as janelas, de vidro escuro, são fixas e mantidas fechadas.

Certa vez, perguntei a uma jurada, que atuara no prédio do antigo $1^{\circ}$ Tribunal, o que ela achava do novo:

ELA: N ossa! N em se compara! Aqui a gente tem a sensação de entrar no futuro, enquanto lá tudo parecia velho e decadente.

Eu: A senhora acha que alguma coisa mudou nos julgamentos em função disso?

ELA: Ah!... Aí eu não sei, porque as pessoas são as mesmas. M as acho queaqui todo mundo se sente mais importante, desde o momento que chega. É como se houvesse al gum poder no ar, entende?

Eu: A senhora poderia explicar mehor? 
ELA: Ah!... Aqui a gente se sente pequeno nesses corredores e parece que o mundo lá fora parou. A gente não ouve barulhos, nem sabe se está chovendo ou fazendo sol. Essa história de terem posto ar-condicionado e vidros escuros, em tudo, também faz a gente se sentir meio estranho, meio isolado.

Eu: E dentro do plenário? A senhora sentiu alguma diferença?

ELA: Por ser tudo novo, moderno, limpinho, parece que todo mundo toma mais cuidado. Como em ônibus novo, sabe? Q uando está tudo brilhando, ninguém suja.

Ev: E que tipo de cuidado a senhora percebe que todo mundo está tomando dentro dos plenários?

ELA: Acho que mesmo no fórum velho, quando as pessoas entravam no plenário, já havia um certo acanhamento: falavam mais baixo, não sentavam de qualquer jeito, não riam. Aqui, continua acontecendo isso, mas porque os plenários são claros, limpos. Parece que tudo está preparado pra cada um agir direito, com respeito, entende?

$\mathrm{N}$ a fala dessa entrevistada, há associações entre características arquitetônicas do novo fórum eemoções queelas inspiram. A magnitude dos espaços e o fato de eles serem novos e limpos são percebidos como elementos que contribuem para que osocupantes sintam-se, ao mesmo tempo, respeitados e respeitosos. A forma como os espaços estão estruturados ganha significados à medida que neles são projetadas lembranças, valores e expectativas.

Excetuando-se esse novo fórum, os outros quatro Tribunais do J úri paulistanos, atéo término de meu trabal ho de campo, em 2001, estavam instalados em prédios que tinham em comum a falta de imponência e de solenidade. O s edifícios, tanto por fora como por dentro, não lembravam os tradicionais e pomposos tribunais que, geralmente, por serem recorrentes em filmes norte-americanos "dejúri", preenchem o imaginário das pessoas. E ram construções que passavam despercebidas na paisagem urbana e, pelo que pude observar, seus corredores e sal as administrativas não causavam nos usuários a sensação de estarem em um espaço especial. Certa sensação de sacralidadesó seimpunha no interior dos próprios plenários, duranteosjulgamentos, devido à força do ritual, de suas regras, hierarquias, interditos e, principalmente, em função do poder que sempre está em jogo durante os julgamentos.

D e um modo geral, esses prédios impessoais tinham aspecto de despojadas repartições públicas. Em suas entradas, costumava haver um ou mais policiais que, dependendo do "jeito" de quem chegava, solicitavam a iden- 
tificação. Eu mesma, só para testar seu "olhar clínico", entrei várias vezes com "jeito de advogada" ou "de estagiária" - roupas contidas e el egantes, ar compenetrado e preocupado, passo apressado, carregando mal eta e processos - , e só fui barrada uma única vez, ocasião em que "saquei" a minha carteira da OAB - Ordem dos Advogados do Brasil - e imediatamente ouvi: "D esculpe, doutora, pode entrar!". Todavia, quando eu lá chegava com "jeito de estudante" - roupas mais despojadas, informais, ol har curioso, pastinha plástica na mão - , ficava em uma posição intermediária entre quem pode ou não ser interceptado. No caso de homens, geralmente basta o uso de terno e gravata para seguirem em frente. 0 fato é que, qualquer pessoa mais simplesmente vestida, geralmente era barrada ou tomava a iniciativa de se barrar, informando quem era, porque está ali e/ou pedindo orientações.

No interior dos corredores, também continuava visível, mediante uma linguagem essencialmente corporal, a diferença entre quem estava lá porque era profissional do júri ou funcionário do tribunal, e quem era réu ou membro de sua família. Réus presos e al gemados chegavam de camburão, por entradas privativas, e eram levados diretamente a ambientes isolados saletas ou mesmo celas -, onde permaneciam vigiados por policiais militares, aguardando o início do julgamento, demodo queo mais comum era só vêlos nos plenários.

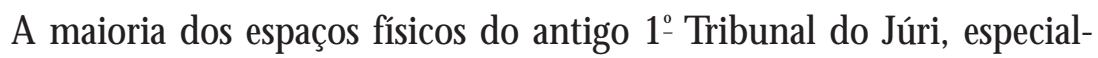
mente seus corredores, lembrava um pouco as clássicas "instituições totais", tanto que, não por mera coincidência, o prédio fora concebido para abrigar uma fábrica. Por si mesmo, ele comunicava a existência de algum tipo de controle, de vigilância e de um poder que atingia os corpos, neles se materializava e por meio deles se exercia (cf. Foucault, 1984).

Q uanto à localização geográfica dos prédios, cabe ressaltar que se encontravam em bairros relativamente centrais da cidade, mais próximos da maioria das residências de operadores do direito e de jurados do que das periferias de onde provinha a quase totalidade de réus e vítimas.

Alguns réus soltos, seus parentes e testemunhas, e mesmo funcionários menos qualificados com quem conversei, declararam que o deslocamento para os fóruns representava horas e dinheiro gastos em várias conduções:

9. Entrevista concedida por uma funcionária do 3ำTribunal do Júri, em 18/3/1999. "M oro do lado de uma delegacia, mas levo mais de uma hora pra chegar aqui. $M$ as tem muito mais delegacia do que tribunal, não é mesmo? Policial, bem ou mal, a gente vêa toda hora. Juiz, tem gente que só vê quando vai pro banco dos réus ou tem quetestemunhar" ${ }^{\prime}$. Enfim, morar longe dos 
tribunais, mais do que um distanciamento geográfico, implica um distanciamento "da Justiça" e "do Estado", embora eles não deixem de semanifestar por seus braços policiais.

0 3-Tribunal do Júri, ainda hoje localizado nos últimos andares de um prédio do bairro de Santo Amaro, parecido com um conjunto de escritórios, permite que de suas janelas se avistem, entre muito verde, grandes mansões de bairros "nobres" da região. U ma tarde, enquanto eu aguardava o início de uma sessão e observava essa paisagem, uma simpática funcionária, quejá mevira por lá al gumas vezes, aproximou-see comentou: "O Ihando ninguém imagina que os crimes que chegam aqui vêm das mais de setecentas favelas que estão para além desse verde bonito...". E eu aproveitei para comentar: "M as os jurados vêm do verde bonito...", ao que ela, sorrindo, acrescentou: "O sjuízes e todos os doutores também! Eu é que não venho nem de lá nem de cá"10. M etáforas definidoras de uma acidentada topografia socioeconômica.

Em outra ocasião, essa mesma funcionária já me perguntara, durante 0 intervalo de uma sessão, se eu era assistente de algum juiz, pois me vira fazendo muitas anotações e, de vez em quando, consultando um código. Ao saber que eu era "somente advogada e pesquisadora", ela comentou: "É que, às vezes, juízes novos que passam no concurso e ingressam na magistratura vêm assistir às sessões, e a gente, não sabendo, pode dar al gum fora". Infelizmente, não houve tempo de eu lhe perguntar a que tipo de fora ela se referia, mas imagino que fosse al go relativo a formas de tratamento e defe rências que, assim como o vestuário e a postura, marcam, como patentes, quem é quem em espaços aparentemente anônimos. Como já bem registrou M auss:

0 corpo éo primeiro e mais natural instrumento do homem. 0 u, mais exatamente, [...] o primeiro e o mais natural objeto técnico, e ao mesmo tempo meio técnico [...]. Essa adaptação constante [do corpo] [...] é efetuada numa série de atos montados, emontados no indivíduo não simplesmente por ele próprio, mas por toda a sua educação, por toda a sociedade da qual faz parte, conforme o lugar que nela ocupa (M auss, 2003, pp. 407-408).

Foi nesse tribunal que comecei a atentar mais para a maneira como as pessoas se percebiam e se identificavam nos plenários, especialmente antes do início das sessões, quando al guns dos potenciais jurados, sentados "na platéia", abordavam-se e entabulavam conversas. Graças a esses momentos
10. Conversa ocorrida em 5/3/1999. 
de aproximações informais, tive e criei oportunidades, nesse e em outros tribunais, de conversar com jurados que, invariavelmente, uma vez esclarecidos de que eu não estava na mesma posição que eles, enquadravam-mena categoria "estudante" e tratavam-me com certo ar professoral.

Para al guns juízes, promotores e advogados, que reiteradas vezes viramme muito atenta, anotando tudo em um "caderninho", eu era alguém em fase de preparação para prestar al gum concurso ou advogar no júri. Ao saberem que eu desenvolvia uma tese de antropologia e também era advogada, passavam a me considerar "quase uma igual", o que me fazia refletir sobre o quanto classificar é, defato, condição sinequa non para estabelecer relações, pois permite a todos al gum posicionamento, seja para criar proximidades ou distâncias.

A proveitei, quase sempre, esse exercício de topografia social, tanto com jurados como com operadores do direito e manipuladores técnicos, para apresentar-me ora como "advogada e pesquisadora", ora como "advogada e antropóloga", ora apenas como "antropóloga e pesquisadora". Os efeitos, como era de se esperar, variavam. A nomenclatura "advogada e pesquisadora" causava melhor impacto do que "advogada e antropóloga" e muito meIhor ainda do que "antropóloga e pesquisadora". Ser antropóloga, sem dúvida, éal go desconhecido de boa parte dos operadores edemais participantes do júri - para não dizer dos participantes do mundo - , de forma que éuma classificação que geralmente não classifica e, por isso mesmo, causa estranhamento e distância.

N esse tribunal, também por várias vezes, ao sair do elevador e encaminhar-me para um dos plenários, funcionários perguntaram-me se eu era jurada, ocasiões em que não pude deixar de pensar em como seria ter ado-

11. Essa opção foi adotada por Sestini (1979). tado o caminho metodológico de tornar-me uma ${ }^{11}$. M as, mal iniciadas as sessões, reconfortava-mea posição de "antropóloga-pesqui sadora-advogada", minha autoclassificação, exatamente nessa exata ordem.

Retomando o fio condutor, talvez para perdê-lo

Tentei apresentar e desenvolver a proposta de que o conjunto das expressões mais correntes nas sessões de júri, apesar de todo o aparato técnico-jurídico envolvido, baseia-se em um vocabulário desentimento (cf. G eertz, 1978, p. 317), o que não implica dizer que, como situação social que põe em relação ao menos dois sistemas de classificação - 0 das leis e regras processuais e o das interpretações dessas leis, regras e acontecimentos da 
vida social -, o júri seja a mera expressão do choque entre a rigidez de códigos legais e a flexibilidade das interpretações feitas por operadores do direito e leigos.

Entendo que, nos plenários, códigos, interpretações e atuações se compõem fazendo sentido como um novo conjunto formado em uma dimensão específica de trocas e interações. 0 s julgamentos, assim, constituem e são constituídos por essa dimensão produtora de significados. Os fatosdramas da vida social, na situação criada nos júris, estão tão longe de seus contextos de origem quanto de um encaixe perfeito a pressupostos legais. Eles se tornaram al go de outra natureza, cujo sentido só se al cança focando o domínio ritualizado, lúdico e poético em que se expressam, no qual tempo e espaço, já vividos, passam a ser imaginados e interpretados. Q uanto maior a heterogeneidade dos significados envolvidos nesse domínio, penso que mais rico ele se torna para cada um dos envolvidos e, especialmente, para observadores da vida social.

D urante as horas das sessões são narrados acontecimentos que se reportam a dias, noites, meses, anos. Embora não se percorram favelas, becos, casas, praças e ruas, nem se escutem tiros e gritos ou se vejam sangue e cadáveres cobertos com folhas de jornal, tudo está ali, transmutado em narrativas. M esmo as páginas dos processos - as fotos que os ilustram, os depoimentos registrados em "assentadas", os laudos periciais e as peças produzidas por juízes, promotores e advogados - que já são, em si, narrativas, tornam a ser narradas no contexto do julgamento, suscitando a produção de novos e múltiplos sentidos.

Essas constatações poderiam ser tomadas simplesmente como argumentos de reforço para aqueles que, contrários à permanência do Tribunal do Júri no Brasil, apontam os jurados como pessoas sem "bom senso jurídico", pois, por motivos emocionais e por serem leigos, desprezam provas "tecnicamente importantes".

0 que desejo lançar nesse debateéjustamenteum argumento que reforça a idéia de quehá vários subtextos contidos no texto do júri, de modo que vivêlo e lêlo com atenção etnográfica implica perceber que tanto o vocabulário de sentimento como os ol hares topográfi cos e o jargão técnico jurídi co são alguns desses subtextos. 0 conjunto, longe de constituir um todo harmônico, representauma experiência coletiva dissonante, com ruídos efissuras e, por isso mesmo, potencialmente mais criativa do que se formasse um conjunto harmônico e homogêneo. A exposição de cada ator a uma situação comum e complexa de aprendizado sentimental e o desafio de nela 
12. Algunschamam de "psicanálise sel vagem" às tentativas de interpretações psicanalíticas por parte de leigos e mesmo de profissionais fora do contexto psicanalítico e, portanto, sem respeito a certos preceitosteóricos, me todológicos e éticos que orientam a prática da psicanálise. Entendo que algo semeIhante ocorre com a sociologia quando utilizada por leigos emesmo por profissionais de outras áreas, em contextos não acadêmicos, paralegitimar opiniões sem a devida referência a - e talvez, sem a consciência de - limites teóricos e metodológicos de certos conceitos e modelos (cf. Schritzmeyer, 2002, p. 113). sistematizarem experiências, tornando-as inteligíveis, parece-me tanto reproduzir desigualdades como possi bilitar questioná-las.

H á, no júri, assim como em outros rituais, uma espécie de idioma geral que possibilita o entendimento de alguns dos múltiplos si gnificados envolvidos e de uma certa "dimensão social do pensamento" (D arnton, 1986, p. XVII). M as justamente porque os vocábulostêm múltiplos al cances, quando textos se reportam a contextos, e vice-versa, uns não se encaixam perfeitamente nos outros e a cada um é dada a chance de (se) reinventar.

Como produtor desse material social, os Tribunais de Júri certamente não são a única nem a melhor das chaves para a compreensão da maneira pela qual o direito reflete, como conjunto de princípios abstratos, processos de significação, até porque, como diria G eertz, "o direito é saber local e não um princípio abstrato [...] ele constrói a vida social em vez de refleti-la" (1998, p. 329). 0 júri, todavia, destaca-se, diante deoutrosespaçosjudiciais dos quaisleigosnão participam como julgadores, enquanto obra imaginativa mais fortemente polifônica, fruto de complexa co-autoria. A presença de leigos nos conselhos de sentença exige dos operadores técnicos argüições mais ricas em uma espécie de matriz que combina jargão técnico-jurídico, imagens deuma "sociologia selvagem" 12 eum vocabulário desentimento. Portanto, penso o júri como um espaço social privilegiado de produção de significações coletivas ao possibilitar que diferentes pessoas organizem e expressem estratégiassi mbólicas por meio das quais lidam com a vida.

Como os agentes do júri não são filósofos, em sentido estrito, pois tanto operadores do direito, manipuladores técnicos, como jurados, réus, testemunhas etc. não pensam a respei to das coisas, mas pensam com as coisas (cf. D arnton, 1986, p. XIV), a cerimônia do júri Ihes oferece coisas especiais com as quais pensar: traições amorosas, tensões entre parentes e vizinhos, pobreza, favelas, subempregos, tráficos de drogas e de armas, além dos discursos dirigidos a jurados sobre pertencerem à "classe média" e serem chamados a julgar "em nome da sociedade".

Sem dúvida, há uma luta, nosjulgamentos, pel o monopólio do estabele cimento deformaslegítimas de "pensar". M asnão éuma luta que, ameu ver, produza com clareza vencedores e vencidos. Sei que esse ponto é polêmico, pois resultados de várias pesquisas apontam uma distribuição desigual de sentenças condenatórias, fazendo especialmente de homens negros, jovens, migrantes, subempregados e pobres alvos privilegiados das sanções punitivas(cf. Adorno, 1994, p. 149). M as, por que, segundo o que pude observar, dificilmente alguém sai de uma sessão de júri tal como nela entrou? Penso 
que não é porque ali somente se reforçam estereótipos que confirmam o statusquo, tampouco porque, no júri, temos um palco querevoluciona hierarquias, tradições e preconceitos. H á algo, no júri, produzido no contato tenso, intenso ecorporal entre diferentes ediferenças que estremece crenças generalizantes, universal istas eapaziguadoras. Algo maisforte do queas sentenças condenatórias e absolutórias. Algo da ordem do questionamento de formas de convívio eda indagação de se outras são possíveis. Algo que segue com cada um, após o juiz declarar encerrada a sessão.

Talvez eu ainda esteja tão impregnada por minhas observações participantes a ponto de interpretar o júri para além de seus limites semânticos. $M$ as ainda bem que não preciso concluir este texto com um veredicto a respeito desses limites, pois a única certeza que tenho, até o momento, é a de que, apesar de também ter me formado em direito, eu teria muita dificuldade em exercer a advocacia, a magistratura, a promotoria pública ou ser jurada nos Tribunais do Júri.

\section{Referências Bibliográficas}

Adorno, Sérgio. (1994), “C rime, justiça penal e desigualdade jurídica: as mortes que se contam no Tribunal do Júri". Revista U SP - D ossiê Judiciário, 21: 132-151, mar./abr., São Paulo.

Alm EIDA, D ario M artins. (1977), 0 livro do jurado. Coimbra, Livraria Almedina.

BALAN DIER, G eorges. (1982), 0 poder em cena. Brasília, Editora da UnB.

Bo RGES, Robinson. (2001), "Licença poética: livro de Steven Lubet afirma que, num julgamento, todo advogado é um contador de histórias". Jornal Valor, 29 e 30 de junho e $1^{\circ} \stackrel{\circ}{=}$ de julho, pp. 10 e 11.

DARnton, Robert. (1986), 0 grande massacre de gatos e outros episódios da história cultural francesa. Rio de Janeiro, Graal.

Foucault, Michel. (1984), Vigiar e punir. Petrópolis, Vozes.

Geertz, Clifford. (1978), “Um jogo absorvente: notas sobre a briga de galos balinesa". In: . A interpretação das culturas. Rio de Janeiro, Zahar, pp. 278-321. . (1991), "Afirmação política: espetáculo e cerimónia". In: . N egara: 0 estado teatro no século XIX. Lisboa, D ifel, pp. 127-152.

. (1998), "O saber local: fatos e leis em uma perspectiva comparativa". In: . 0 saber local: novos ensai os em antropologia interpretativa. Rio de Janeiro, Vozes, pp. 249-356.

GinzBurg, Carlo. (1989), “O inquisidor como antropólogo”. In: A microhistória. Lisboa, Difel, pp. 203-214. 
H olston , James. (1993), A cidade modernista: uma crítica de B rasília esua utopia. São

Paulo, Companhia das Letras.

Lubet, Steven. (2001), N othing but the truth: why trial lawyersdon't, can't and shouldn't have to tell the whole truth. N ova York, N ew York University Press.

M Auss, M arcel. (2003), "As técnicas corporais". In: Sociologia e antropologia.

São Paulo, Cosac N aify, pp. 401-422.

Peiran o, M ariza. (org.). (2002), 0 dito e o fei to: ensai os de antropologia dos rituais. Rio de Janeiro, Relume D umará/N úcleo de Antropologia da Política/U FRJ.

Schritzm Eyer, Ana Lúcia Pastore. (2002), Controlando o poder de matar: uma leitura antropológica do Tribunal do Júri: ritual Iúdico e teatralizado. São Paulo, Tese de doutorado. Programa dePós-G raduação em Antropologia Social, Faculdade deFiIosofia, Letras e Ciências H umanas da Universidade de São Paulo. . (2007), "Tribunal do Júri: dramatizações da vida através de complexos jogos narrativos". In: Schritzm Eyer, Ana Lúcia Pastore et al. A criminologia no século XXI. Rio de Janeiro, Lumen Júris, pp. 7-35.

SEST IN I, M aria Alice Travaglia. (1979), 0 Tribunal do Júri: uma forma de distribuição da justiça. Campinas. Dissertação de mestrado. IFCS - Instituto de Filosofia e Ciências H umanas da Unicamp.

\section{Resumo}

Etnografia dissonante dos tribunais do júri

A partir de etnografia realizada, entre 1997 e 2001, nos cinco Tribunais do Júri da cidade de São Paulo, questiono se tribunais, em geral, e os do júri, em particular, se esgotam como arenas de luta nas quais o binômio dominação-sujeição se realiza de forma privilegiada. Sustento que, embora observemos, nesses espaços, rituais que reiteram hierarquias tradicional mente estabelecidas, el es também permitem a construção de novas subjetividades e a redefinição de experiências sociais. Os fatos-dramas reconstituídos nos júris estão longe de seus contextos originais tanto quanto da possibilidade de se explicarem legalmente. Eles são de outra natureza, cujo sentido só se al cança no domínio ritualizado, lúdico e poético de sua própria expressão.

Palavras-chave: Tribunais do Júri; Etnografia; O bras coletivo-imaginativas.

\section{Abstract}

Jury Courts: dissonant ethnography

Ethnographical research carried out between 1997 and 2001 of the five Jury C ourts in the city of São Paulo leads me to ask whether courts in general, and the Jury Court in particular, can be explained merely as arenas of conflict and privileged sites for the 
interplay of domination and subjection. Although in such places we can observe rituals that reinforce traditionally established hierarchies, they also allow for the construction of new subjectivities and the redefinition of social experiences. The facts/dramas reconstructed in the courts are as far removed from their original contexts as they are from the possibility of being explained from a legal perspective alone. They are of a different nature and their meaning can only be understood from within the ritual, playful and poetic domains of their own expression.

Keywords: Jury C ourts; Ethnography; I maginative/C ollective Works.

Texto recebido e aprovado em 20/9/2007.

Ana Lúcia Pastore Schritzmeyer é professora do D epartamento de Antropologia da FaculdadedeFilosofia, Letras e C iências H umanas daUSP. E-mail: alps@usp.br. 